\title{
High and Low Sodium Biotypes of Fourwing Saltbush: Their Responses to Sodium and Potassium in Retorted Oil Shale
}

\author{
STEVEN G. RICHARDSON
}

\begin{abstract}
Two of 5 populations of fourwing saltbush (Atriplex canescens) examined in eastern Utah did not accumulate appreciable amounts of sodium in leaf tissue while 3 populations did accumulate sodium in leaves. The characteristics of sodium accumulation and nonaccumulation were exhibited in these populations when leaf tissue was collected from plants growing in the field or from plants grown in saline retorted oil shale in 2 greenhouse pot experiments. The plants that were low in sodium were higher in potassium but lower in total sodium plus potassium. Growth of plants from the low sodium populations was enhanced by addition of potassium to the retorted oil shale but potassium addition had no effect on growth of the high sodium plants. Top growth of the high sodium plants was greater than growth of the low sodium plants on retorted oil shale.
\end{abstract}

A common characteristic of desert halophyte species of the Chenopodiaceae family is the accumulation of large concentrations of mineral ions in leaf tissues (Wallace et al. 1973, Wiebe and Walter 1972). Accumulation of salts in leaves may affect palatability (Wallace et al. 1973) and soil salinity (Sharma and Tongway 1973). The various genera and species may differ in the amounts and even the kinds of ions accumulated. For example, greasewood (Sarcobatus vermiculatus) had high concentrations of sodium in leaves while spiny hopsage (Grayia spinosa) in the same plant community had high potassium concentrations in leaves but only very low sodium concentrations (Rickard 1965). This paper reports the identification of sodium-accumulating and nonsodium-accumulating populations of fourwing saltbush (Atriplex canescens). The paper also compares sodium and potassium concentrations in leaves as affected by $\mathrm{Na}$ and $\mathrm{K}$ in the growth medium and growth characteristics of the two types when grown in saline retorted oil shale with and without added potassium.

\section{Methods}

\section{Field Survey}

Leaves were collected from a total of 23 fourwing saltbush plants in 5 populations (groups of plants several miles apart) in the vicinity of Bonanza, Uinta County, Utah, on July 26, 1978. The leaves were oven-dried at $80^{\circ} \mathrm{C}$ for $24 \mathrm{hrs}$., ground, and extracted with deionized water. The extracts were analyzed for sodium (Na) and potassium $(\mathrm{K})$ by atomic absorption spectrophotometery. Stem cuttings were collected from each of the 23 plants and propagated in the greenhouse by the methods of Richardson et al. (1979) for use in subsequent studies.

\section{Greenhouse Experiments}

The first of 2 greenhouse experiments was designed to verify the

At the time of the research, the authors were associate professor and professor, Department of Wildlife and Fisheries Sciences; and professor, Department of Range Science, Texas A\&M University, College Station, 77843.

Authors are grateful to P.H. Welder for furnishing land and herbicide treatment for the research, J.L. Mutz and K. Caerley for their assistance in conducting the research, and Julia Scifres for manuscript typing and preparation.

Manuscript received August 2, 1981 . existence of high and low sodium biotypes as suggested from the field survey and to compare the effects of different salinity levels on concentrations of $\mathrm{Na}$ and $\mathrm{K}$ in leaves.

Paraho retorted oil shale from Anvil Points, Colo., was leached with distilled water to reduce the salinity to an ECe (electrical conductivity of a saturation extract) value of $4.1 \mathrm{mmho} / \mathrm{cm}$. The leached Paraho shale contained $0.2 \mathrm{meq}$ (milliequivalents) $\mathrm{Na} / 100 \mathrm{~g}$ and $0.1 \mathrm{meq} \mathrm{K} / 100 \mathrm{~g}$. Eighty $24 \mathrm{oz}$. cottage cheese cartons were each filled with $700 \mathrm{~g}$ oven-dried, leached shale that had been sieved through a $6.35-\mathrm{mm}$ mesh screen. Half the pots were treated with $100 \mathrm{ml}$ of sodium sulfate solution, with an EC of 42 $\mathrm{mmho} / \mathrm{cm}$, which brought the ECe of the retorted shale to 18.6 $\mathrm{mmho} / \mathrm{cm}$. All pots were fertilized with $100 \mathrm{ppm} \mathrm{N}, 44 \mathrm{ppm} \mathrm{P}$, and $83 \mathrm{ppm} \mathrm{K}$ by weight. Four replicates of 5 low sodium and 5 high sodium plants, chosen at random, were planted as rooted cuttings into the low salinity $(\mathrm{ECe}=4.1 \mathrm{mmho} / \mathrm{cm})$ and the high salinity $(\mathrm{ECe}=18.6 \mathrm{mmho} / \mathrm{cm})$ retorted shale. Soil moisture was raised to $20 \%$ by weight and maintained at that level by daily weighed additions of distilled water. Following 60 days of growth in a greenhouse, leaves were harvested, dried, ground and analyzed for soluble $\mathrm{Na}$ and $\mathrm{K}$ with an atomic absorption spectrophotometer.

In the second experiment, the effects of $\mathbf{K}$ added to retorted oil shale on leaf $\mathrm{Na}$ and $\mathrm{K}$ concentrations and on plant growth were examined. Sixty-four $24 \mathrm{oz}$. size cottage cheese cartons were each filled with $700 \mathrm{~g}$ Union B retorted Utah oil shale previously sieved through a $6.35 \mathrm{~mm}$ mesh screen. The ECe of the retorted shale was $8.0 \mathrm{mmho} / \mathrm{cm}$. The water soluble sodium $(\mathrm{Na})$ concentration was $2.0 \mathrm{meq} / 100 \mathrm{~g}$, and the water soluble potassium $(\mathrm{K})$ concentration was $0.1 \mathrm{meq} / 100 \mathrm{~g}$. Each pot of retorted shale was fertilized with $103 \mathrm{ppm} \mathrm{N}$ (as calcium nitrate) and $34 \mathrm{ppm} P$ (as sodium phosphate). Half the pots were treated with $100 \mathrm{ppm} \mathrm{K}$ (as potassium sulfate).

Four high sodium plants and 4 low sodium plants were selected at random from the 23 plants previously collected from the field near Bonanza, Utah. Rooted cuttings were planted in the pots of shale and the shale was watered to $20 \%$ moisture by weight, which was maintained by daily weighing and watering with distilled water. The experimental design was a randomized block in factorial arrangement with 2 plant types, 4 plants per type, 2 potassium concentrations, and 4 replicates. After 60 days of growth in a greenhouse, plant tops were harvested, dried at $80^{\circ} \mathrm{C}$ for 24 hours, and weighed. Leaves were separated, ground,extracted with distilled water, and analyzed for $\mathrm{Na}$ and $\mathrm{K}$ by atomic absorption spectrophotometry.

\section{Results}

In the field survey 3 populations had leaf sodium concentrations greater than $100 \mathrm{mmole} / 100 \mathrm{~g}$, while 2 populations had less than 10 mmole $\mathrm{Na} / 100 \mathrm{~g}$ leaf dry matter (Table 1). Potassium concentrations in leaves were high when sodium concentrations were low. The sum of Na plus $\mathrm{K}$ concentrations in leaves was higher in the populations where $\mathrm{Na}$ in leaves was also greater. 
Table 1. Sodium and potassium concentrations in fourwing saltbush leaves collected from 5 populations in eastern Utah.

\begin{tabular}{|c|c|c|c|c|c|}
\hline \multirow[b]{2}{*}{ Associated vegetation } & \multirow[b]{2}{*}{ Population } & \multirow{2}{*}{$\begin{array}{c}\text { Number of } \\
\text { plants sampled }\end{array}$} & \multicolumn{3}{|c|}{ Soluble ions in oven-dry leaves (mmole $/ 100 \mathrm{~g})^{1}$} \\
\hline & & & $\mathrm{Na}$ & $\mathrm{K}$ & $\mathrm{Na}+\mathrm{K}$ \\
\hline $\begin{array}{l}\text { Sagebrush, greasewood, } \\
\text { shadscale }\end{array}$ & $\mathbf{A}$ & 6 & $103 \pm 18$ & $53 \pm 7$ & $156 \pm 13$ \\
\hline Sagebrush, greasewood & $\mathbf{B}$ & 3 & $141 \pm 7$ & $28 \pm 1$ & $169 \pm 7$ \\
\hline Sagebrush, shadscale & $\mathrm{C}$ & 6 & $136 \pm 19$ & $34 \pm 3$ & $170 \pm 13$ \\
\hline Shadscale, grass & $\mathrm{D}$ & 4 & $4 \pm 1$ & $71 \pm 10$ & $75 \pm 10$ \\
\hline $\begin{array}{l}\text { Sagebrush, juniper, } \\
\text { greasewood }\end{array}$ & $\mathbf{E}$ & 4 & $9 \pm 5$ & $81 \pm 4$ & $90 \pm 3$ \\
\hline
\end{tabular}

${ }^{1}$ Mean values \pm standard error.

When the plants were grown on Paraho retorted oil shale in the greenhouse the same pattern of sodium and potassium concentrations in leaves existed as was found in the field survey (Table 2). The plants that were low in leaf sodium in the field remained lower in sodium, higher in potassium and lower in $\mathrm{Na}$ plus $\mathrm{K}$ than the plants that had high leaf sodium in the field. An increase in sodium sulfate salinity of the retorted oil shale resulted in increased Na plus $\mathrm{K}$ concentrations in leaves, but the increase was greater in the high sodium plants. The high sodium plants responded to higher salinity with increased concentrations of $\mathrm{Na}$ in leaves while low sodium plants responded primarily with increased $\mathbf{K}$ concentration in leaves.

Addition of $\mathrm{K}$ to the Union $\mathrm{B}$ retorted shale caused a greater increase in leaf $\mathrm{K}$ in the low $\mathrm{Na}$ plants than in the high $\mathrm{Na}$ plants (Table 3). There was a slight decrease in leaf $\mathrm{Na}$ with the addition of $\mathrm{K}$ to the shale. There were also differences in $\mathrm{Na}$ and $\mathrm{K}$ contents of leaves among plants within each biotype. This was also observed in the other experiment and in the field survey.

Top growth of the high sodium plants was greater than top growth of the low sodium plants (Table 4). Addition of $\mathbf{K}$ to the retorted shale caused increased growth of the low sodium plants but not the high sodium plants. The analysis of variance (not shown) also revealed that plant differences within each plant type were significant (.01 level). Although $K$ had a significant effect on the low sodium plant type, the overall effect when data for low sodium and high sodium plants were combined wa not significant at the .05 level. None of the interactions were significant.

\section{Discussion}

The data show that distinct biotypes of fourwing saltbush exist with regard to sodium accumulation. Interspecific crosses in nature among various saltbush species are not uncommon (Blauer et al. 1976, Stutz and Sanderson 1977). It is possible that the high sodium biotype of fourwing saltbush may possess genes for sodium accumulation derived from another Atriplex species that absorbs large amounts of sodium. If this were true, greater growth of the high sodium biotype than the low sodium biotype might be due to hybrid vigor. Fourwing saltbush is not the only species of saltbush that may tend to exclude sodium and absorb large amounts of potassium. Breckle (1974) also found that $A$. falcata growing in

Table 2. Sodium and potassium concentrations in leaves of low sodium and high sodium biotypes of fourwing saltbush grown in leached Paraho retorted oil shale and leached shale plus sodium sulfate.

\begin{tabular}{lcccc}
\hline \hline Biotype & $\begin{array}{c}\text { Shale ECe } \\
(\mathrm{mmho} / \mathrm{cm})\end{array}$ & \multicolumn{3}{c}{ Mineral concentrations (mmole/ 100g) } \\
\cline { 3 - 5 } Low sodium & 4.1 & $2 \pm 0.2$ & $\mathrm{Na}$ & $\mathrm{Na}+\mathrm{K}$ \\
& 18.6 & $13 \pm 1.9$ & $139 \pm 4.7$ & $100 \pm 5.5$ \\
High sodium & 4.1 & $50 \pm 8.9$ & $71 \pm 3.7$ & $120 \pm 11.4$ \\
& 18.6 & $128 \pm 14.7$ & $68 \pm 5.5$ & $196 \pm 18.7$
\end{tabular}

IECe values were $4.1 \mathrm{mmho} / \mathrm{cm}$ for the leached shale and $18.6 \mathrm{mmho} / \mathrm{cm}$ for leached shale plus sodium sulfate.

${ }^{2}$ Data are mean values \pm standard error. very saline soils just north of the Great Salt Lake in Utah had this same tendency for sodium exclusion and potassium accumulation. Some differences in $\mathrm{Na}$ and $\mathrm{K}$ accumulation among individual plants within each fourwing saltbush biotype were also noted in this study. Inheritance of the traits could be complex, involving multiple alleles rather than simple dominant and recessive genes. Thus a broad spectrum of degrees of sodium accumulation or nonaccumulation could be possible.

Wallace et al. (1973) and Wallace and Romney (1972) reported much lower sodium levels in fourwing saltbush leaves than in leaves of other saltbush species. Wallace et al. (1973) suggested that the low sodium content of fourwing saltbush relative to many other saltbush species is one reason for its high forage value. If this is true, then forage value (possibly palatability or oxalate content) would likely differ between the high sodium and low sodium biotypes of fourwing saltbush.

The lack of correlation between ash content of fourwing saltbush and soil salinity in a study by Welch (1977) may be due to the existence of sodium-accumulating and sodium-excluding biotypes. Sodium compounds are usually the primary contributors to soil salinity, but soil pota ssium is probably more closely related to mineral or ash content of the low sodium biotype than is soil sodium.

The high sodium biotype of fourwing saltbush apparently has a lower potassium requirements than the low sodium biotype. The lower requirement for $\mathrm{K}$ in the high sodium biotype may be due to an ability to use $\mathrm{Na}$ as a partial substitute for $\mathrm{K}$. The apparent partial substitution of sodium for potassium in plant nutrition has also been observed in other species by other researchers (e.g., Hylton et al. 1967, Harmer and Benne 1945, Dow and James 1970, Ulrich 1961).

Accumulation of salts (particularly sodium salts) in leaves with subsequent leaf fall causes an increase in surface soil salinity and sodicity beneath saltbushes and other halophytes (Sharma and Tongway 1973, Rickard and Keough 1968, Eckert and Kinsinger 1960). Such salt accumulation at the soil surface may adversely affect establishment of herbaceous understory species and thus may affect plant community development. Rickard et al. (1973) found that soil collected beneath spiny hopsage, which accumulates potassium in leaves, was more favorable to the growth of cheatgrass (Bromus tectorum) than was soil beneath greasewood, which accumulates sodium in leaves. Similarly, the low sodium fourwing saltbush biotype may provide a more favorable environ-

Table 3. Sodium and potassium concentrations (mmole $/ 100 \mathrm{~g})^{1}$ in leaves of high sodium and low sodium biotypes of fourwing saltbush grown on Union B retorted oil shale with and without added potassium.

\begin{tabular}{lcccc}
\hline \hline Biotype & $\begin{array}{c}\text { K added } \\
(\mathrm{ppm})\end{array}$ & $\mathrm{Na}$ & $\mathrm{K}$ & $\mathrm{Na}+\mathrm{K}$ \\
\hline Low sodium & 0 & $12 \pm 4.9$ & $115 \pm 10.1$ & $127 \pm 8.6$ \\
& 100 & $11 \pm 4.5$ & $133 \pm 6.7$ & $143 \pm 6.3$ \\
High sodium & 0 & $70 \pm 4.5$ & $92 \pm 7.4$ & $162 \pm 4.6$ \\
& 100 & $58 \pm 4.7$ & $107 \pm 10.3$ & $165 \pm 7.3$ \\
\hline
\end{tabular}

1 Mean values of four replicates \pm standard error. 
Table 4. Top growth (g/pot)' of high sodium and low sodium biotypes of fourwing saltbush as affected by potassium addition to Union B retorted oil shale.

\begin{tabular}{|c|c|c|}
\hline $\begin{array}{r}\text { added } \\
\text { (ppm) }\end{array}$ & $\begin{array}{l}\text { Low sodium } \\
\text { biotype }\end{array}$ & $\begin{array}{l}\text { High sodium } \\
\text { biotype }\end{array}$ \\
\hline $\begin{array}{r}0 \\
100\end{array}$ & $\begin{array}{l}2.81^{*} \\
3.24^{*} \\
3.03^{* *}\end{array}$ & $\begin{array}{l}4.11 \\
4.16 \\
4.14^{* *}\end{array}$ \\
\hline
\end{tabular}

IMean values of 4 replicates

-Significantly different at .05 level

**Significantly different at .01 level

ment for understory species than the high sodium fourwing saltbush biotype would. This could be especially important where roots of deep-rooted saltbush penetrate a soil covering and come into contact with saline retorted oil shale.

The sodium accumulating and sodium excluding biotypes of fourwing saltbush differed in production, potassium requirement, and sodium and potassium concentrations in leaves. There is reason to believe that the biotypes may also differ in salt tolerance, palatabilty, and effects on soil properties. Thus existence of the two biotypes may have implications for disturbed land rehabilitation and management of salt desert shrub rangelands. Further research is needed to ascertain the extent of sodium accumulation and nonaccumulation ( $\mathrm{Na}$ exclusion) in fourwing saltbush and other saltbush species, to define the inheritance patterns of the characteristics, and to determine the ecological and management significance of this physiological phenomenon.

\section{Literature Cited}

Blauer, A.C., A.P. Plummer, E.D. MacArthur, R. Stevens, and B.C. Guinta. 1976. Characteristics and hybridization of important intermountain shrubs. II Chenopod family. USDA FS Rs. Pap. INT-177. Intermountain Forest and Range Exp. Sta., Ogden, Utah.
Breckle, S.W. 1974. Wasser-und salzverhaltnisse bei halophyten der salzsteppe in Utah/USA. Ber. Deutsch. Bot. Ges. Bd. 87:589-600.

Dow, A.I., and D.W. James. 1970. Potassium deficiency and potassiumsodium relationships in central Washington irrigated alfalfa. Proc. 21 st Ann. Fertilizer Conf. of the Pacific Northwest, Salt Lake City, Utah.

Eckert, R.E., Jr., and F.E. Kinsinger. 1960. Effects of Halogeton glomeratus leachate on chemical and physical characteristics of soils. Ecology 41:764-772.

Harmer, P.M., and E.J. Benne. 1945. Sodium as a crop nutrient. Soil Sci. 60:137-148.

Hylton, L.O., A. Ulrich, and D.R. Cornelius. 1967. Potassium and sodium interrelations in growth and mineral content of Italian ryegrass. Agronomy J. 49:311-314.

Richardson, S.G., J.R. Barker, K.A. Crofts, and G.A. Van Epps. 1979. Factors affecting rooting of stem cuttings of salt desert shrubs. J. Range Manage. 32:280-283.

Rickard, W.H., and R.F. Keough. 1968. Soil-plant relationship of two steppe desert shrubs. Plant and Soil 29:205-212.

Rickard, W.H. 1965. Sodium and potassium accumulation by greasewood and hopsage leaves. Botan. Gaz. 126:116-119.

Sharma, M.L., and D.J. Tongway. 1973. Plant induced soil salinty patterns in two saltbush (Atriplex spp.) communities. J. Range Manage. 26:121125.

Stutz, H.C., and S.C. Sanderson. 1977. Natural hybridization of Atriplex canescens $\times A$. tridentata in Utah and Nevada. Proc. 30th annual meeting of the Soc. Range Manage., Portland, Oregon.

Ulrich, A. 1961. Plant analysis in sugar beet nutrition. In: plant analysis and fertilizer problems. Amer. Inst. Biol. Sci. Pub. No. 8.

Wallace, A., and E.M. Romney. 1972. Radioecology and ecophysiology of desert plants at the Nevada test site. TID-25954 USAEC Technical Information Center, Oak Ridge, Tenn. 439 p.

Wallace, A., E.M. Romney, and V.Z. Hale. 1973. Sodium relations in desert plants. I. Cation. contents of some species from the Mojave and Great Basin deserts. Soil Sc. 115:284-287.

Welch, B.L. 1977. Relationship of soil salinity, ash and crude protein in Atriplex canescens. J. Range Manage. 31:132-133.

Wiebe, H.H., and H. Walter. 1972. Mineral ion composition of halophytic species from northern Utah. Amer. Midland Natur. 87:241-245. 